\title{
UPAYA MENINGKATKAN HASIL BELAJAR IPS PESERTA DIDIK DENGAN MENGGUNAKAN MODEL PEMBELAJARAN KOOPERATIF TIPE TWO STAY TWO STRAY (STST) PADA KELAS VII-B MTS MIFTAHUL JANNAH PALANGKA RAYA
}

\author{
Oleh \\ Astinah,* M. Ramli** \\ Email:M.ramli@yahoo.com
}

\begin{abstract}
This study aims to find out the learning activities and increase the learning outcomes of social studies students. The method used in this study was to use the Classroom Action Research (CAR) design. Subjects needed in this study were students of class VII-B MTs MifTahul Jannah Palangka Raya, which numbered 23 students, for data collection techniques used were observation and tests. While in this study using qualitative and quantitative data analysis. The results of the study show that: (1) There is an increase in learning outcomes. This can be known at the initial stage with an average value of 64 with classical completeness of $26.08 \%$ experiencing an increase in the first cycle which reached an average of 72 with classical completeness of $56.52 \%$ and the results achieved by students in this second cycle of grades the average increased from the previous cycle, which reached an average value of 82 . This indicates that learning using the Two Stay Two Stray Model (TSTS) was said to be successful with classical completeness values of $86.95 \%$ in class VII-B MTs Miftahul Jannah Palangka Raya .
\end{abstract}

(C) Muhammadiyah University Palangkaraya

Keywords: IPS Learning Outcomes, Model Two Stay Two Stray (TSTS).

\begin{abstract}
ABSTRAK
Penelitian ini bertujuan untuk mengetahui aktivitas belajar dan peningkatan hasil belajar IPS peserta didik. Metode yang digunakan dalam penelitian ini adalah menggunakan rancangan Penelitian Tindakan Kelas (PTK). Subjek yang dibutuhkan dalam penelitian ini adalah peserta didik kelasVII-B MTs MifTahul Jannah Palangka Raya yang berjumlah 23 orang peserta didik, untuk teknik pengumpulan data yang digunakan adalah observasi dan tes. Sedangkan dalam penelitian ini menggunakan analisis data kualitatif dan kuantitatif. Hasil penelitian menunjukan bahwa: (1) Ada peningkatan hasil belajar. Hal ini dapat diketahui pada tahap awal dengan nilai ratarata yaitu 64 dengan keuntasan klasikal 26,08\% mengalami peningkatan pada siklus I yakni mencapai rata-rata 72 dengan ketuntasan klasikal 56,52\% dan hasil yang dicapai peserta didik pada siklus II ini nilai rata-rata lebih meningkat dari siklus sebelumnya yaitu mencapai nilai rata-rata 82 hal ini menunjukkan bahwa pembelajaran menggunakan Model Two Stay Two Stray (TSTS) dikatakan berhasil dengan nilai ketuntasan klasikal yaitu 86,95\% di kelas VII-B MTs Miftahul Jannah Palangka Raya.
\end{abstract}

(C) Universitas Muhammadiyah Palangkaraya

Kata Kunci: Hasil Belajar IPS,Model Two Stay Two Stray (TSTS). 


\section{PENDAHULUAN}

Pendidikan adalah suatu proses pelatihan dan pengajaran, terutama diperuntukkan kepada anak-anak remaja, baik disekolah-sekolah maupun dikampus- kampus, dengan tujuan memberikan pengetahuan dan pengembangan keterampilanketerampilan. Sebagai suatu proses, pendidikan dimaknai sebagai semua tindakan yang mempunyai efek pada perubahan watak, kepribadian, pemikiran, dan perilaku. Dengan demikian, pendidikan bukan sekedar pengajaran dalam arti kegiatan menstransfer ilmu, teori, dan fakta-fakta akademik semata atau bukan sekedar ujian, penetapan kriteria kelulusan, serta percetakan ijazah semata.

Upaya untuk meningkatkan kemampuan peserta didik dalam proses pembelajaran selama ini merupakan masalah yang sering ditemui dalam proses belajar mengajar, berbagai usaha dikembangkan untuk meningkatkan kemempuan peserta didik dalam proses pembelajaran dengan menerapkan berbagai stategi pembelajaran.

Penentuan strategi yang tepat untuk meningkatkan hasil belajar peserta didik merupakan tugas seorang guru sebagai pendidik, berdasarkan dari hasil tersebut diatas, maka penelitian perlu mengubah strategi pemebelajaran dikelas dengan pembelajaran Kooperetif Tipe Two Stay Two Stray (TSTS), yang dirancang untuk membuat peserta didik lebih aktif dalam mengikuti pembelajaran dikelas.

Belajar merupakan suatu proses perubahan yaitu perubahan tingkah laku sebagai hasil dari interaksi dengan lingkunganya dalam memenuhi kebutuhan hidupnya. Perubahanperubahan tersebut akan nyata pada seluruh aspek tingkah laku. Belajar adalah suatu proses usaha yang dilakukan seseorang untuk memperoleh suatu perubahan tingkah laku yang baru secara keseluruhan, sebagai hasil pengalaman sendiri dalam interaksi dengan lingkunganya.

Menurut Slameto (2013:2)

Perubahan yang terjadi dalam diri seseprang banyak sekali baik sifat maupun jenisnya karena itu sudah tentu tidak setiap perubahan dalam diri seseorang merupakan perubahan dalam arti belajar.

Menurut Oemar Hamalik (2014:28) Belajar merupakan suatu proses, suatu kegiatan dan bukan suatu hasil atau tujuan. Belajar bukan hanya mengingat, akan tetapi lebih luas dari itu, yakni mengalami. Hasil belajar bukan suatu penguasaan hasil latihan melainkan perubahan tingkah laku. Tujuan belajar prinsipnya sama, yakni perubahan tingkah laku, hanya berbeda cara atau usaha pencapaiannya. Pengertian ini menitik beratkan pada interaksi antara individu dengan lingkungan. Di dalam interaksi inilah terjadi serangkaian pengalamanpengalaman belajar. Belajar bukan suatu tujuan tetapi merupakan suatu proses untuk mencapai tujuan. Jadi, merupakan langkah-langkah atau prosedur yang ditempuh.

Menurut Brahim (Susanto, 2013:5) hasil belajar adalah sebagai tingkat keberhasilan peserta didik dalam mempelajari materi pelajaran di sekolah yang dinyatakan dalam skor yang 
diperoleh dari hasil belajar tes mengenal sejumlah materi pelajaran tertentu. Sedangkan menurut Sudjana (2010:22) hasil belajar adalah kemampuankemampuan yang dimiliki peserta didik setelah menerima pengalaman belajarnya dan hasil peserta didik pada hakikatnya adalah perubahan tingkah laku.

Berdasarkan pendapat-pendapat diatas, maka disimpulkan bahwa hasil belajar peserta didik dengan melalui proses kegiatan pembelajaran yang sudah dirancang guru sehingga setelah kegiatan belajar mengajar peserta didik memperoleh pengalaman-pengalaman belajar dan memilliki tingkat penguasaan dalam materi pelajaran untuk mengetahui tinggi, sedang, dan rendahnya hasil belajar.

Setiap proses belajar yang dilaksanakan oleh peserta didik akan menghasilkan hasil belajar. Di dalam proses pembelajaran, guru sebagai pengajar sekaligus pendidik memegang peranan dan tanggung jawab yang besar dalam rangka membantu meningkatkan keberhasilan peserta didik dipengaruhi oleh kualitas pengajaran dan faktor intern dari peserta didik itu sendiri.

Menurut Slamet, dkk, (Lenie Rusmiatie, 2015:15) menerangkan tentang hasil belajar bahwa ilmu pengetahuan sosial atau yang dikenal dengan istilah IPS di Indonesia dimulai sejak tahun 1970-an sebagai hasil kesepakatan komunitas akademik dan secara formal mulai digunakan dalam sistem pendidikan nasional dalam kurikulum 1975. Dalam dokumen tersebut IPS merupakan salah sayu nama mata pelajaran yang diberikan pada jenjang pendidikan dasar dan menengah.

Berdasarkann penjelasan diatas dapat disimpulkan bahwa hasil belajar IPS adalah penilaian yang dicapai seseorang peserta didik untuk mengetahui tingkat pemahamanya dan bertujuan agar mata pealajaran ini lebih bermakna dari peserta didik.

Menurut Amri (2013:9) Model pembelajaran adalah sebagai suatu desain yang menggambarkan proses rincian dan penciptaan situasi lingkungan yang memungkinkan peserta didik berinteraksi sehingga terjadi perubahan atau perkembangan pada diri peserta didik. Sedangkan menurut Miftahul Huda (2013:207) mengemukakan bahwa metode TS-TS merupakan sistem pembelajaran kelompok dengan tujuan agar siswa dapat saling bekerja sama, bertanggung jawab saling membantu memecahkan masalah, dan saling mendorong satu sama lain untuk berprestasi.

Dari pendapat diatas dapat disimpulkan bahwa pembelajaran kooperatif tipe Two Stay Two Stray (TSTS) adalah salah satu model pembelajaran kooperatif dengan cara siswa bekerja dalam kelompok yang terdiri dari empat orang siswa lalu, dua diantaranya bertemu kekelompok lain dengan tujuan mencari informasi mengenai materi dan dua orang siswa tinggal dalam kelompok untuk menerima kunjungan dari kelompok lain, kemudian memberikan kesempatan kepada kelompok membagikan hasil dan informasi.

Penggunaan model pembelajaran Two Stay Two Stray (TSTS) pada 
pembelajaran IPS di VII-B MTs Miftahul Jannah Palangka Raya, diharapkan dapat meningkatkan hasil belajar IPS peserta didik. Pada saat proses pembelajaran, model ini mengajak peserta didik untuk berpatisipasi aktif secara langsung. Sehingga, peserta didik akan lebih mudah menguasai apa yang dipelajari. setiap model menajak pembelajaran pasti memiliki kekurangan, tetapi kekurangan itu bukan suatu kendala melainkan sebagai cara untuk mengantisipasi masalah yang ada, serta kelebihan yang ada pada model pembelajaran ini dijadikan sebagai acuan atau pedoman untuk menjadikan pembelajaran yang lebih aktif, kreatif dan menyenangkan.

Model pembelajaran kooperatif adalah salah satu model pembelajaran yang digunakan oleh guruuntuk menarik keaktifan peserta didik dalam proses pembelajaran. Peserta didik tidak hanya berperan sebagai pendengar dan pengamat saja, tetapi peserta didik dapat lebih kreatif dan kritis menanggapi sesuatu baik itu berupa pertanyaan, pernyataan dan pendapat yang terjadi sebagai pemecahan masalah yang diberikan dalam kelompok.

Berdasarkan penjelasan tersebut, maka tujuan penelitian ini adalah untuk mendekripsikan aktivitas belajar IPS peserta didik dengan menggunakan model pembelajaran tipe Two Stay Two Stray (TSTS) pada kelas VII-B MTs Miftahul Jannah Palangka Raya dan untuk meningkatan hasil belajar IPS dengan menggunakan pembelajaran melalui tipe Two Stay Two Stray
(TSTS) pada kelas VII-B MTs Miftahul Jannah Palangka Raya.

\section{METODE PENELITIAN}

Jenis Penelitian yang digunakan dalam penelitian ini adalah Penelitian Tindakan Kelas (PTK) yang bertujuan untuk melakukan perbaikan-perbaikan terhadap sistem, isi, dan konpetensi atau situasi pembelajaran dengan menguji cobakan suatu ide kedalam praktik dan situasi nyata dalam proses belajar mengajar dikelas dengan harapan kegiatan tersebut dapat meningkatkan hasil proses belajar mengajar.

Menurut Diplan dan Andi Setiawan (2018:120) Penelitian Tindakan Kelas adalah penelitian yang dilakukan oleh guru dengan maksud untuk melihat kemampuan diri dan memperbaiki kualitas proses pembelajaran kelas, sehingga hasil belajar siswa dapat ditingkatkan, aktifitas belajar peserta didik menjadi semakin baik dan aktif.

Penelitian tindakan kelas (PTK) adalah suatu peranan yang sangat penting dan starategis untuk meningkatkan mutu untuk memperbaiki diri sendiri dan pengalaman kerja sendiri.

\section{HASIL DAN PEMBAHASAN}

Data awal penelitian ini yaitu data yang diperoleh dari data observasi dan tes awal (pre test) peserta didik. Kedua data ini akan menjadi tolak ukur keberhasilan dari pembelajaran atau tindakan penelitian kelas yang akan dilakukan. Berdasarkan data awal observasi hasil belajar peserta didik masih dibawah standar KKM yang 
ditentukan sekolah. Dari jumlah 23 peserta didik perempuan 13 atau $56,52 \%$ yang mencapai KKM sedangkan 10 atau $43,48 \%$ belum mencapai KKM. Kurangnya keaktifan siswa dalam pembelajaran membuat kegiatan belajar terlihat membosankan. Sehingga hasil belajar peserta didik masih rendah.

Berdasarkan tes awal (pre test) dilakukan terhadap peserta didik dikelas

VII-B MTs Miftahul Jannah Palangka Raya pada hari Jum'at, 20 April 2018 yang berjumlah 23 orang dengan 20 butir soal dalam bentuk pilihan ganda tentang materi kehidupan manusia pada masa Praaksara dan belum diberikan proses pembelajaran menggunakan model pembelajaran $T w o$ StayTtwo Sray (TSTS).

1. Aktivitas Belajar Peserta Didik Ketika Menggunakan Model Pembelajaran Tipe Two Stay Two Stray (TSTS)

Hasil observasi peserta didik berdasarkan pengamatan kedua observer yaitu guru mata pelajaran IPS dan teman sejawat bahwa skor aktivitas belajar peserta didik pada siklus I secara individual terdapat 13 orang peserta didik yang memperoleh Skor $\geq 75$ dan 10 orang peserta didik yang memperoleh skor $\mathbf{S 7 5}$ dengan skor rata-rata 2,85 sehingga pada siklus I belum bisa dikategorikan baik. skor aktivitas belajar peserta didik pada siklus II secara individual terdapat 19 orang peserta didik yang memperoleh skor $\geq 75$ dan 4 orang peserta didik yang memperoleh skor $\leq 75$ dengan skor rata-rata 3,78 sehingga aktivitas peserta didik pada siklus II sudah dapat dikategorikan baik.

2. Hasil Belajar Peserta Didik Setelah menggunakan Model Pembelajaran Tipe Two Stay Two Stray (TSTS)

Hasil belajar yang diperoleh berdasarkan hasil tes pada peserta didik kelas VII-B MTs MifTahul Jannah Palangka Raya menggunakan model pembelajaran tipeTwo Stay Two Stray (TSTS)mengalami peningkatan di setiap siklusnya.

Sesuai dengan data temuan hasil analisis keaktifan dan peningkatan hasil belajar peserta didik setelah perbaikan dengan menggunakan model pembelajaran tipe Two Stay Two Stray (TSTS), terbukti dapat mencapai hasil yang lebih baik dari sebelummnya. Dalam pelaksanaan peningkatan hasil belajar peserta didik pada pembelajaran IPS, terbukti telah terjadi peningkatan ketuntasan hasil belajar secara klasikal memperoleh ketuntasan klasikal awal 26,08\% dengan kategori (tidak tuntas), sehingga diperlukan refleksi siklus I ditunjukkan dengan perolehan nilai rata-rata 72 dengan ketuntasan klasikal 56,52\% dengan kategori (tidak tuntas). Setelah melakukan perbaikanperbaikan berdasarkan refleksi pada siklus I, maka di dapatkan 
perolehan siklus II dengan nilai rata-rata mengalami peningkatan dengan baik yaitu 82 dengan ketuntasan klasikal $86,95 \%$ dengan kategori tuntas.

\section{KESIMPULAN}

Berdasarkan hasil penelitian yang telah di bahas maka dapat di simpulkan sebagai berikut:

1. Aktivitas Belajar Peserta didik kelas VII-BMTs Miftahul Jannah Palangka Raya lebih baik setelah menggunakan model pembelajaran kooperatif tipe $T w o$ Stay Two Stray (TSTS)pada pelajaran IPS. Hasil aktivitas peserta didik siklus I dengan ratarata 2,85 kategori baik dan siklus II skor nilai dengan rata-rata 3,78kategori baik.

2. Ada peningkatan hasil belajar IPS peserta didik setelah diajarkan dengan menggunakan Model Two Stay Two Stray (TSTS) di kelas VII-B MTs Miftahul Jannah Pahandut Seberang Palangka Raya. Hal ini dapat diketahui pada tahap awal dengan nilai rata-rata yaitu 64 dengan keuntasan klasikal 26,08\% mengalami peningkatan pada siklus I yakni mencapai rata-rata 72 dengan ketuntasan klasikal 56,52\% dan hasil yang dicapai peserta didik pada siklus II nilai rata-rata lebih meningkat dari siklus sebelumnya yaitu mencapai nilai rat-rata 82 hal ini menunjukkan bahwa pembelajaran menggunakan Model Two Stay Two Stray (TSTS) dikatan berhasil dengan nilai ketuntasan klasikal yaitu $86,95 \%$ di kelas VII-B MTs Miftahul Jannah Pahandut Seberang Palangka Raya.

\section{DAFTAR PUSTAKA}

Amri, sofan. (2013). Pengembangan \& Model Pembelajaran Dalam Kurikulum 2013. Jakarta: Prestasi Pusaka karya

Diplan \& Setiawan, M.A. (2018). Penelitian Tindakan Kelas. Yogyakarta: Deepublish

Hamalik, Oemar. (2014). Proses Belajar Mengajar. Jakarta: Bumi Aksara.

Lenie Rusmiate. (2015). Peningkatan Hasil belajar IPS Pesertadidik dengan Menggunakan Media Visual yang tak Diproyeksikan di Kelas VIII SMP Negeri 2 Tasik Payawan Tahun Pelajaran 2014/2015. Skripsi Universitas Muhammadiyah Palangkaraya: Tidak diterbitkan

Miftahul Huda. (2013). Model-Model Pengajaran dan Pembelajaran. Yogyakarta: Pustaka Pelajar

Slamet. (2013). Belajar dan Faktorfaktor yang mempengaruhi. Jakarta: Rineka Cipta. Sudjana. (2010). Dasar-dasar Proses Belajar. Bandung: Sinar Baru

Sudjana. (2010). Dasar-dasar Proses Belajar. Bandung: Sinar Baru

Susanto.(2013). Teori Belajar dan Pembelajaran Di Sekolah Dasar. Jakarta: Kencana Prenada Media Group. 